\title{
Measuring and Explaining regulatory Reform in the EU A Time Series Analysis of Eight Sectors, 1984-2012
}

\author{
Citi, Manuele; Justesen, Mogens Kamp
}

Document Version

Final published version

Publication date:

2013

\section{License \\ CC BY-NC-ND}

Citation for published version (APA):

Citi, M., \& Justesen, M. K. (2013). Measuring and Explaining regulatory Reform in the EU: A Time Series Analysis of Eight Sectors, 1984-2012. Department of Business and Politics. Copenhagen Business School. Working Paper / Department of Business and Politics No. 85

Link to publication in CBS Research Portal

\section{General rights}

Copyright and moral rights for the publications made accessible in the public portal are retained by the authors and/or other copyright owners and it is a condition of accessing publications that users recognise and abide by the legal requirements associated with these rights.

\section{Take down policy}

If you believe that this document breaches copyright please contact us (research.lib@cbs.dk) providing details, and we will remove access to the work immediately and investigate your claim. 
Copenhagen Business School

HANDELSHøJSKOLEN

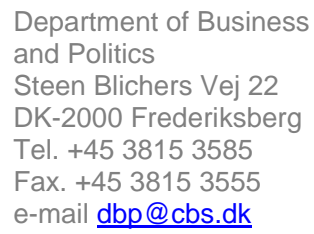

Measuring and Explaining Regulatory Reform in the EU:

A Time Series Analysis of Eight Sectors, 1984-2012

Manuele Citi \& Mogens K. Justesen 
Working paper no 85, 2013

Editor: Lita Lundquist

Department of Business and Politics

Copenhagen Business School

Steen Blichers Vej 22

DK-2000 Frederiksberg

Phone: +45 38153585

E-mail: dbp@cbp.cbs

www.cbs.dk/dbp

ISBN: 87-91690-91-9 


\title{
Measuring and Explaining Regulatory Reform in the EU:
}

A Time Series Analysis of Eight Sectors, 1984-2012

\author{
Manuele Citi \\ Copenhagen Business School
}

Mogens K. Justesen ${ }^{+}$

Copenhagen Business School

\begin{abstract}
Over the last three decades, EU regulation of the internal market has become highly pervasive, affecting practically all the domains of European citizens' lives. Many studies have focused on understanding the process and causes of regulatory reform. However, these have typically been small-scale or small-n studies, with no or limited attempts to analyse the more general sources of regulatory reform. In this paper, we focus on the determinants of stability and change in EU regulation. We develop an original dataset of 169 pieces of legislation (regulations, directives and decisions) across eight different sectors, and analyse the dynamics of regulatory reform in the EU. Using time series analysis of count data, we find evidence that the number of winning coalitions in the Council and the size of EU membership have a significant impact on regulatory reform in the EU. However, the political (left-right) composition of EU's legislative bodies has no significant impact on the process of regulatory reform.
\end{abstract}

\footnotetext{
* Corresponding author: Department of Business and Politics, Copenhagen Business School, Porcelænshaven 1, DK-2000 Frederiksberg C., Denmark; e-mail: mc.dbp@cbs.dk, phone: +45 38153394.

+ Department of Business and Politics, Copenhagen Business School, Porcelænshaven 1, DK-2000 Frederiksberg C., Denmark; e-mail: mkj.dbp@cbs.dk, phone: +45 38153564.
} 


\section{Introduction}

The historical role played by the EU in promoting regulatory reform in Europe is widely recognised in the literature on EU market integration (Majone 1996; Scharpf 1996; Héritier et al. 2001; Young 2007). This literature has generally identified two phases of market integration. The first phase was eminently de-regulatory and culminated with the Cassis de Dijon case in 1979, and aimed at removing all the national-level barriers that could prevent or constrain free trade across the European Community. The second phase - also known as the re-regulatory or 'positive integration' phase (Scharpf 1996) - was aimed at reconstructing at the supranational level the set of rules that were abolished at the national level, in order to make the common market work properly. A large volume of research has focused on this second phase (e.g. Harcourt \& Radaelli 1999; Egan 2001; Quaglia 2007; Baskoy 2008; Kassim 2010), and in particular on the shifting paradigms of regulation and the process of regulatory change. These studies, however, have typically adopted a qualitative research design, which has prevented broader generalizations on the patterns and drivers of regulatory change in the EU. As a consequence, a number of important questions have not yet been properly addressed by the literature: to what extent does regulatory reform in the EU follow a general and consistent pattern of incremental change? And what are the political and institutional conditions that explain the stability and change in regulatory policies?

In this paper we address these questions. We make two contributions to the literature. First, following a recently developed method for measuring change in regulatory policy outputs (Knill et al. 2012), we develop a new and original dataset of EU regulatory legislation across eight different areas in the utilities sector (electricity, gas, telecommunications and postal services) and transport sector (road, railway, maritime and air transport) and analyse how these regulations have changed over a period of 29 years (1984-2012). These data provide a new and unique source of information on regulatory reforms within the EU. Second, we investigate the influence of a number of EU-level political and institutional variables on the process and pattern of regulatory reform. Specifically, we examine how regulatory reform is affected by the change in legislative procedure (particularly the change from consultation/cooperation to co-decision, which added a new formal veto player), the ability to form winning coalitions in the Council (determined by the changing QMV thresholds and voting weights), the enlarging membership of the EU, and the different level of 'policy entrepreneurship' of the Commission.

The paper develops as follows: The next section reviews the literature concerned with the problem of measuring policy outputs, explaining the particular challenges offered by regulatory 
policies and showing how some recent measurements developed in the literature can be employed to quantify regulatory reform in the eight areas studied in this paper. We also explain the three-tier coding scheme used for the analysis of legislative provisions. The following section presents a number of political and institutional variables that may contribute to explain stability and change in regulatory legislation. Subsequently, we use regression models for count data to examine the institutional and political sources of regulatory reform within the sectors covered by our data. The final section concludes on the main findings.

\section{The problem of measuring regulatory policy change}

The study of policy stability and change has advanced considerably in the last couple of decades. We can identify at least two branches of this literature. The first - which is mainly theoretical focuses on the conceptualization of different types of policy change, and is based on taxonomies classifying different degrees of policy reforms, from small policy adjustments to large-scale policy reforms. This branch was initiated by Peter Hall with his path-breaking study on policy paradigms and the three orders of change (Hall 1993), and has successively been developed by a number of authors, who have gradually refined and enriched Hall's famous typology (Coleman et al. 1996; Cashore \& Howlett 2007; Howlett \& Cashore 2009; Henstra 2011).

The second branch has a more empirical approach, and has centred on the quantitative analysis of policy dynamics in the long run, based on large comparative datasets. Baumgartner and Jones have pioneered this approach by studying how policy stability and change propagate through the different stages of the policy process, producing a considerable volume of evidence on the punctuated-equilibrium dynamic of policy reform (Baumgartner \& Jones 1993; 2002; Jones et al. 2003; Jones \& Baumgartner 2005). The same type of analysis has been replicated by various scholars affiliated with the policy agendas network, finding similar patterns of policy reform across different countries (Jones et al. 2009), and even at the supranational level, as in the case of the European Union (Citi 2013).

These two branches of the literature have co-existed for quite a long time, with limited constructive dialogue. On the one hand, the conceptual work has developed nuanced taxonomies of policy changes, but has not devised proper tools for operationalizing and measuring their concepts. On the other hand, those who have focused their attention on the empirical long-term policy dynamics have accumulated considerable evidence of punctuated-equilibrium dynamics affecting the decision-making processes of different political systems. However, there has been a general 
neglect of the crucial theoretical distinctions made by Hall (1993), i.e. the distinction between policy settings, policy instruments, and policy goals, pooling all the different dimensions of policy change into one: the change in budgetary size of the government's programs. While this reduction of complexity to one dimension is only appropriate for measuring change in distributive (or redistributive) policies - i.e. those policies leaving a footprint in the budget - it is not a viable approach for studying change in regulatory legislation, where a distinction between policy ends, tools, and settings is still key for the development of a valid and reliable measure of policy change.

Recent attempts to combine the two perspectives constitute an important advancement in this field. Knill et al. (2012) in particular have shown how a clear differentiation between policy ends, policy tools, and policy settings makes the operationalization and measurement of regulatory policy change on three different levels possible. Their approach involves counting events of regulatory expansion and regulatory dismantling at the three levels of analysis, on the basis of a specifically developed three-tier coding procedure. At the first level, policies are represented as multidimensional choices, pursuing several different targets. For instance, competition policy can target cartels, mergers and acquisitions, the abuse of dominant positions, the use of state aid, or all of them at different points in time. Any time a new piece of regulatory legislation adds a new target to the status quo policy, this is counted as an event of regulatory expansion. At the second level, we have policy tools, which are the specific ways in which policy targets are materially implemented. This can, for instance, be the imposition of certain obligations, procedures, penalties, taxes/levies or standards, the creation of an independent authority for the pursuit of the same targets, or the extension of its regulatory powers. Any time a new regulatory act mandates the use of a new/additional policy tool, this is counted as an event of regulatory expansion. In contrast, if a new legislative act repeals some existing regulatory policy tools, this is counted as an event of policy dismantling. Finally, policy settings are the concrete settings of the chosen policy tools, and any new provision that strengthens the current settings or makes them stricter, are counted as events of regulatory expansion, whereas the loosening of the current settings are counted as events regulatory dismantling. Hence, if we stick to the example of competition policy, the provision of a higher fine for cartels or market sharing agreements would count as an even of regulatory expansion.

The data resulting from the coding of these three levels of regulatory legislation represent in numerical terms the 'trajectories' of regulatory reform, which can then be combined to calculate two key variables: one variable that captures the change in regulatory density, and a second variable that captures regulatory intensity. Regulatory density is calculated by summing all the new policy 
targets and instruments introduced by new legislation over a given period of time, e.g. over yearly cycles. The reason why it is called regulatory density is that the variable represents the overall concentration of provisions affecting a given policy area within a given period of time. The second variable, however, is called regulatory intensity because it measures the extent to which the existing regulatory instruments are made tougher or softer. In this paper, we use the change in regulatory density as our key dependent variable, as our data show that the overall changes in regulatory intensity across the eight sectors have been minimal and in practice negligible.

\subsection{New data on regulatory change}

This paper draws on the method developed by Knill et al. (2012) to measure the extent to which EU legislation regulating eight key network industries has changed over three decades (1984-2012). The data we develop contain the entire population of regulations, directives and decisions regulating the eight sectors within the time period 1984-2012. The relevant acts (169 acts in total) were collected through EurLex using the following method: we started from the current legislation in force in the eight sectors, and then chain-referred these acts to the act that they intended to amend or repeal (we used the 'relationship between documents' section of the EurLex for this purpose), up to the point where we either hit the base year (1984) or did not find any previous legislation.

The procedure for coding legislation started with the first layer: we checked whether the new regulatory act was addressing a new policy goal (or 'target') not addressed by previous legislation, and in case it did, we codified this as an event of regulatory expansion. For instance, if a new act regulating air transport addressed for the first time the issue of liberalization of groundhandling services, we coded it as a new policy target, and hence as an event of regulatory expansion. We then moved to the second layer: policy instruments. We investigated whether the act introduced new policy instruments and classified them according to our codebook (codes 101-118), which is available in Appendix I. ${ }^{1}$ For example, if the act introduced a fine for maintaining monopolies in the groundhandling sector, this was codified as an event of regulatory expansion. Finally, we looked at the third layer: policy settings. If the new act made the existing policy instrument stricter (e.g. a higher fine for monopolistic behaviour in the groundhandling sector), this was counted as an event of regulatory expansion. All provisions going in the opposite direction (e.g. cancellation of existing policy instruments or softening of existing policy settings) were coded as events of regulatory dismantling. To give an example, in year 2008 we counted two regulations affecting the air

\footnotetext{
${ }^{1}$ The appendix is available at https://sites.google.com/site/mkjustesen/
} 
transport sector (216/2008 and 1008/2008), which were coded as producing a total of 16 events of regulatory expansion: one new policy target (harmonization of flight safety standards) and 15 new policy instruments. No events of regulatory dismantling were identified in this year.

Despite the fact that the method of analysis for change in policy output follows the method developed by Knill et al. (2012), the latter was developed for codifying regulation in the field of environmental legislation. Therefore, we carefully adapted the coding procedure to capture the specificities and the complexity of regulation within the network industries. More specifically, we introduced several new codes to capture the wide range of procedures that are typically employed for liberalizing the network industries (ownership unbundling of the network, equality in third party access, public service obligations etc.). More details of the codebook are available in Appendix I.

\section{Explaining regulatory change: Institutional and political sources}

How can we explain variations in regulatory change within the EU? To address this question, we consider two groups of variables: institutional and political variables. The first group of variables captures the changing institutional landscape of the EU in the last 30 years, and their impact on the capability of the EU to reform its policies. In particular, we focus on those changes to the legislative process that have either increased the number of veto points (e.g. the granting of veto power to the Parliament), or reconfigured the composition of collective veto players (e.g. new members joining the EU and its Council), or changed the voting procedures in the Council. The second group of variables are political, i.e. variables that are related to the changing political composition of the Parliament and the Council, with the consequent reconfiguration of policy preferences within these legislative bodies (along the dimension of a higher or lower degree of market regulation). In the group of political variables, we include a variable that tracks the higher or lower level policy entrepreneurship of the Commission, which has historically varied depending on the stronger or softer 'styles' of Commission's leadership (Peterson 1999) and on changing degrees of informal agenda-setting powers (Pollack 2003: 51-53). In what follows, we explain the hypothesised role of these variables.

\subsection{Institutional variables}

We start with a variable that is central in determining the extent to which political institutions constrain political actors' ability to reform status quo policies: the number of veto players (Tsebelis 2002: 25). In the context of the EU, two institutional changes have added a veto point to the 
legislative system: the introduction of Codecision I with the Maastricht Treaty, which gave the European Parliament the role of quasi-veto player, and the introduction of Codecision II with the Amsterdam Treaty, which gave the Parliament the status of formal veto player (Tsebelis 2002: 256259). In this study we focus in particular on Codecision II (coded as a dummy variable in the dataset), since the high level of collinearity of Codecision I and Codecision II does not it make possible to evaluate the independent effect of Codecision I on the legislative process.

The second institutional variable is the number of EU member states, i.e. the process of EU enlargement, which might have a constraining effect on the EU legislative process. Several works in the literature have stressed this possibility, especially due to the fact that an enlarged membership may have introduced preference heterogeneity within the EU Council, with the effect of constraining the Council's ability to make decisions (Hosli 1999; König \& Bräuninger 2004; Zimmer et al. 2005; Veen 2011).

The third institutional variable is related to the Council's voting procedure. Since the Single European Act introduced qualified majority voting (QMV) for issues dealing with the internal market, the established threshold for a qualified majority in the Council as well as the number of votes allocated to each member state, have been subject to change. Consequently, the size of the unanimity core, as well as the size of the status quo winset, has not remained stable. For instance, the Treaty of Nice introduced a triple majority, which resulted in an increase in the unanimity core of the Council (Tsebelis 2002: 270-271), whereas the Treaty of Lisbon simplified the Council voting procedure, significantly reducing the number of states whose support is necessary to adopt or reform policies (Tsebelis 2012). In order to capture these changes to the unanimity core and to the status quo winset of the Council, we rely on a variable that measures the percentage of winning coalitions out of the total number of possible coalitions determined by each combination of QMV threshold and voting weights. This measure, which is used elsewhere in the literature on veto players (Tsebelis 2006; 2012), is similar to measures used in power index analysis and quantifies the extent to which certain combinations of QMV thresholds and voting weights allow the building of winning coalitions in the Council. ${ }^{2}$ High values on the coalition value denote that the number of winning coalition as a fraction of the total number of coalitions is high, which means that there are fewer institutional constraints on policy-making. In such circumstances, it should therefore be easier to form coalitions favouring regulatory reform.

\footnotetext{
2 The number of winning coalitions is calculated with software developed by Thomas Bräuninger, called Indices of Power - IOP 2.0, available on http://www.tbraeuninger.de/download/
} 


\subsection{Political variables}

The second set of covariates is a small number of political variables that have been identified by the literature as having a potentially significant influence on the output of the policy process. In particular, the political composition of the EU Parliament, Commission and Council, i.e. the 'colour' of their majorities, is thought to have a substantial impact on regulatory legislation (Kreppel \& Tsebelis 1999; Tsebelis \& Garrett 2000; Gabel \& Hix 2002; Hix 2008: 40-49). There are two reasons for this claim. The first is that centre-left and centre-right majorities have historically had opposing policy preferences with regard to common market regulation: the former has normally favoured highly regulated markets, whereas the latter has typically preferred a more laissez faire approach. The second reason is that since the EU Parliament has been granted veto power on first-pillar policies, discordant majorities in the Council and the Parliament can produce policy gridlocks, perpetuating status-quo oriented policy choices (Hix 2008: 45). Hence, we test the impact of the political composition of these three bodies on regulatory reform in the eight sectors, as well as the effect of discordant majorities in the Parliament and in the Council. The time series data we employ for this purpose are extracted from the dataset developed by Klüver and Sagarzazu (2013), which estimates the political composition and orientation of the Commission, the Parliament and the Council, based on the Comparative Manifesto Project (CMP).

Another political variable that is potentially important in determining stability and change in regulatory legislation is the degree of 'policy entrepreneurship' of the Commission, i.e. its capability to set the substantive agenda of policy reform for the EU legislators (Pollack 2003: 47). Policy entrepreneurship involves a number possible initiatives aimed at promoting policy reform. These range from pre-legislative activities (producing white papers, green papers, policy reports), to prioritising issues on the EU agenda, and presenting new legislative proposals that can gather enough consensus in the Council and the Parliament. Different Commissions have historically been characterized by different degrees of policy entrepreneurship, and this could be one of the key determinants of regulatory reform in the EU. Hence, we take the yearly number of legislative proposals initiated by the Commission (directives, regulations and decisions) as a proxy indicator for the level of policy entrepreneurship of the Commission. Moreover, considering that each legislative proposal can take up to two years before it is adopted, we include lagged values of this variable. The data are from the EUPOL dataset (Häge 2011). ${ }^{3}$ Summary statistics for all variables are available in Table A1 in the Appendix.

\footnotetext{
3 Data available at http://frankhaege.eu/
} 


\section{Regulatory change over time}

We start the empirical analysis by showing how regulatory reform has evolved over time within the eight sectors analysed in this paper. In general, the eight sectors are characterized by differing volumes of regulatory legislation. As Figure 1 shows, sectors like air transport, railway transport and telecommunications contain a higher number of events of regulatory expansion than maritime transport or postal services. This tendency appears clearly from the cumulative frequencies of regulatory changes, shown in light grey in Figure 1.

\section{Figure 1. Change in regulatory density}

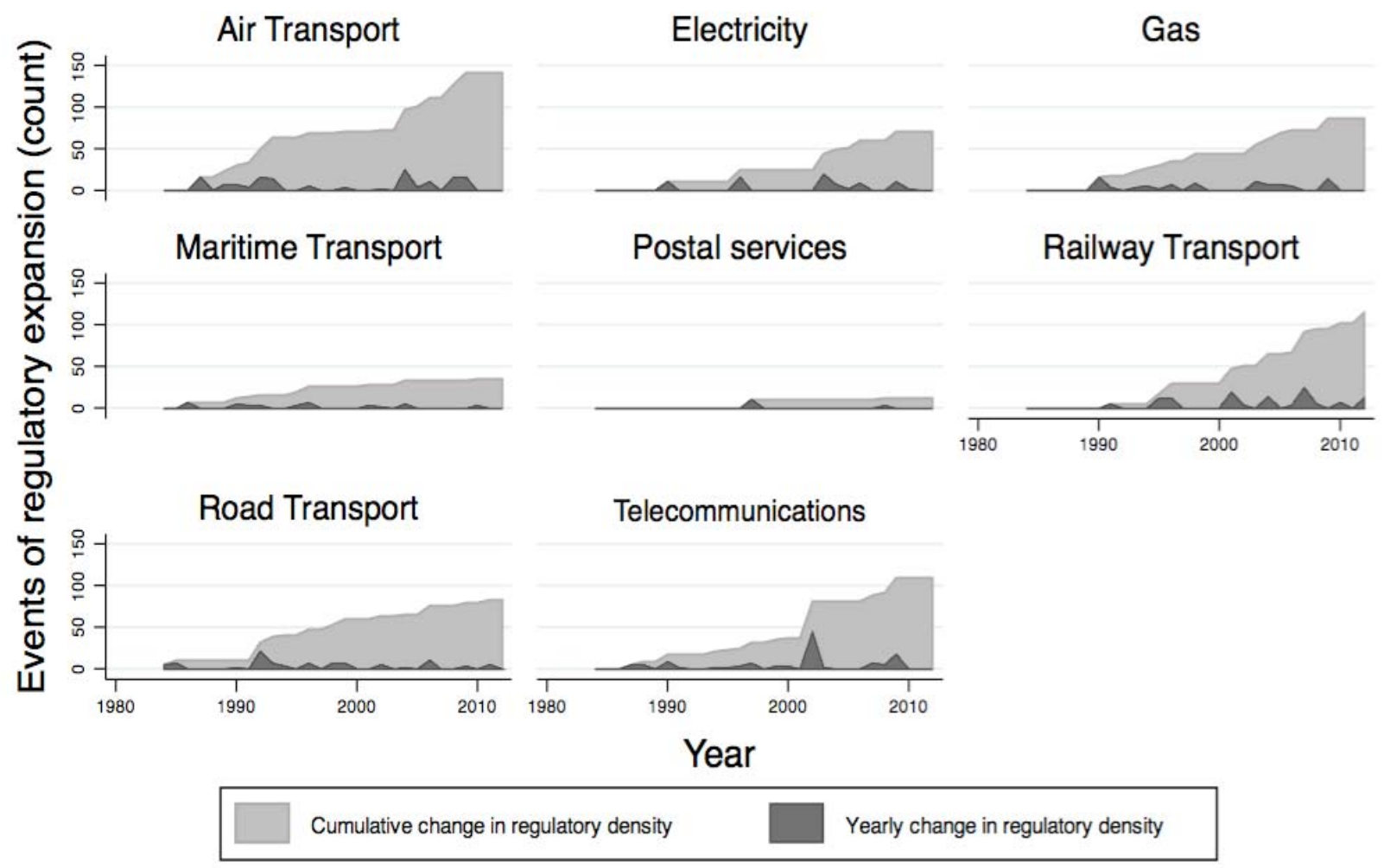

This is mostly due to the important role played by technology in the former sectors, the volume of safety provisions within these sectors, and the high number of provisions associated with the building of the trans-European networks. The focus of our analysis, however, is on the yearly changes in regulatory density, which is independent of the overall volume of legislation in each sector. The general pattern of regulatory reform is characterized by a great deal of policy stability 
and incrementalism, and by a very limited number of spikes of regulatory expansion, as shown in the dark-grey area of Figure 1.

However, in this paper we are interested in the general pattern and sources of regulatory change. Therefore, we collapse regulatory changes across the eight sectors into one variable, measuring the overall change in regulatory density. This is shown Figure 2 and serves as the dependent variable in the econometric analysis. As Figure 2 shows, aggregating the sectors into one variable implies that the distribution of regulatory changes becomes less skewed compared to the distribution of the individual sectors. However, while the number of regulatory changes span from a minimum of three to a maximum of 61 , the median number of regulatory changes across sectors is 16 , supporting the idea the regulatory reform in general is relatively incremental.

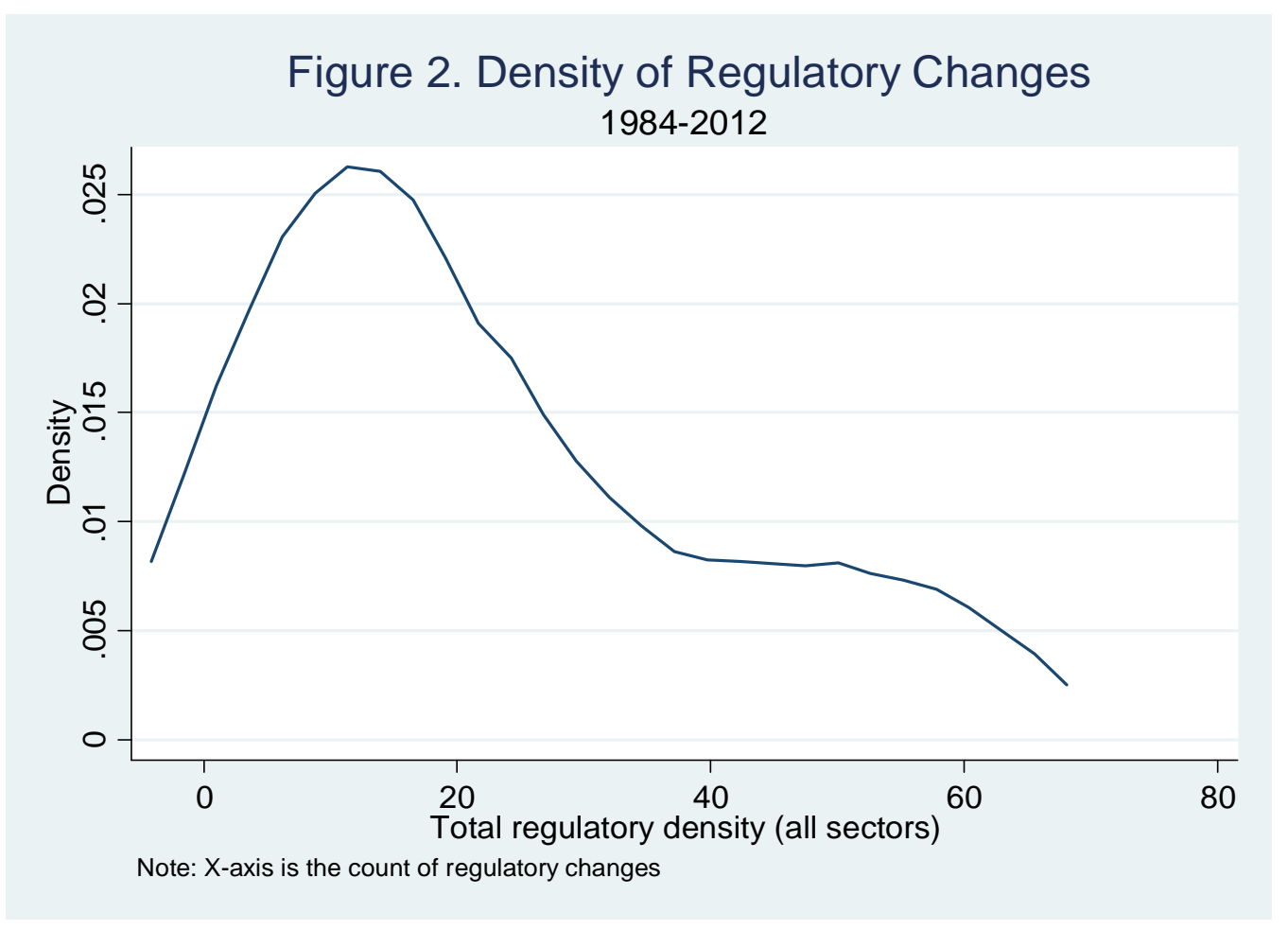

\section{Estimation}

By construction, the dependent variable - the yearly changes in regulatory density across eight industries - is a nonnegative integer or count variable. We therefore use regression models for count data to analyse the impact of the explanatory variables on regulatory changes. While the Poisson regression model is a common starting point for analyses of count data, an important property of the Poisson distribution is that the data are equidispersed, meaning that the variance is equal to the 
mean (Cameron \& Trivedi 2005: 670). However, count data often exhibit a property known as overdispersion, which means that the variance exceeds the mean. Violation of the Poisson model's equidispersion property has consequences similar to violation of the homoscedasticity assumption in linear regression (Cameron \& Trivedi 2005: 670; Long \& Freese 2006: 376). That is, overdispersion leads to downward bias in the standard errors and inflated z-values. One way to deal with this issue is to use the negative binomial regression model, which relaxes the equidispersion property of the Poisson model by allowing for overdispersion in the data (Cameron \& Trivedi 2005: 674-675; Long \& Freese 2006: 372). As shown below, there is quite strong evidence of overdispersion in our data, and for this reason we use the negative binomial regression model rather than the Poisson model. As an alternative, we also perform a logarithmic transformation of the dependent variable to make it more normally distributed, and use the logarithmically transformed count of regulatory changes as dependent variable in OLS regressions to check the robustness of the results. To economize on space, results from the OLS regressions are shown in Appendix A, but they are qualitatively similar to the results obtained from the count models.

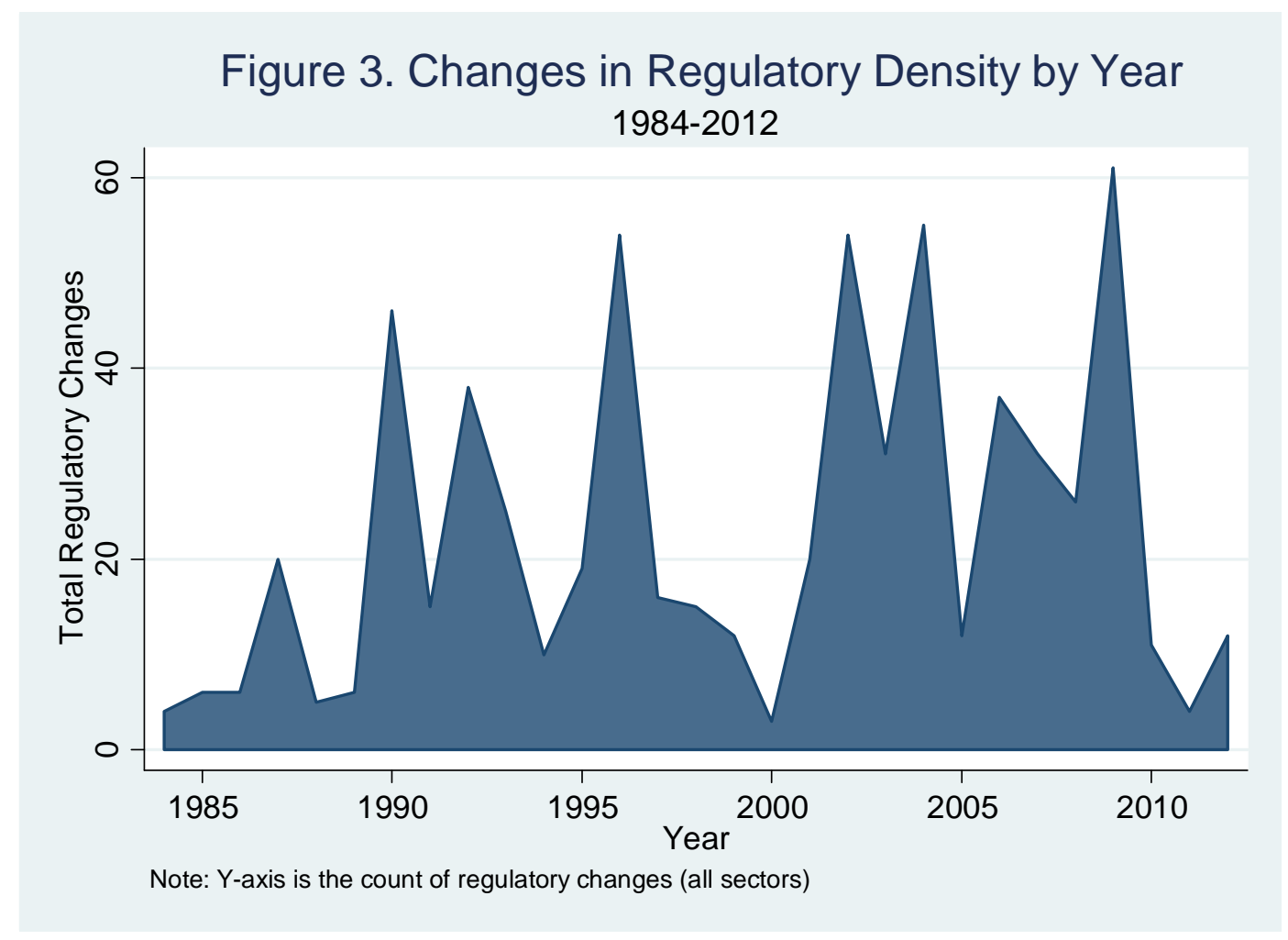

Before we proceed with the regressions, we check the time-series properties of the data. As a starting point, plotting the time series of changes in regulatory density - as done in Figure 3 - does 
not reveal any apparent trend in the dependent variable, which could suggest that the time series is stationary. However, to formally test whether the dependent variables follow a unit root process, we use the augmented Dickey-Fuller test to check for a unit root in the count of regulatory changes and the logarithmically transformed regulatory changes. These tests clearly reject the null-hypothesis of a unit root in the time series of regulatory changes (the critical value is $Z(t)=3.73$ at the $1 \%$ level). We also check for serial correlation in the residuals (results are reported in Table 1 below). In the negative binomial regressions, we do so by obtaining the response residuals - the difference between the observed and expected count - and then use the Portmanteau (Q) statistic to test for residual serial correlation. We also run a simple autoregressive model of the current residuals on the lagged residuals as an additional test for serial correlation. In both cases, the tests clearly fail to reject the null-hypothesis of no serial correlation. In the OLS regressions (Appendix A), we use Durbin's alternative test and the Breusch-Godfrey test to check for first-order serial correlation. Again, the tests do not reject the null-hypothesis of no serial correlation. Overall, these tests do not provide evidence of significant time-series dynamics in the form of non-stationarity and serial correlation in the data.

\section{Results}

Table 1 shows results from 12 negative binomial regressions with the count of yearly changes in regulatory density as the dependent variable. All explanatory variables are included contemporaneously (year $t$ ). The reason for this is that institutional and political constraints in year $t$ determine the scope of regulatory reform in year $t$. The only exception is the legislative proposals variable which is lagged one year $\left(t_{-1}\right)$. The reason for lagging legislative proposals is that the vast majority of the regulatory reforms (roughly 80\%) take up to 12 months to go through the decisionmaking process (Klüver \& Sagarzazu 2013: 394). However, in models 1-6, we do not include the number of legislative proposals as an explanatory variable because it may serve as an intervening variable in relation to at least some of the other variables. For instance, it is plausible that the ability to form winning coalitions - and the corresponding constraints on decision-making powers - affects the capability of the Commission to act as a policy entrepreneur, and in this way affects the number of legislative acts proposed by the Commission. This could lead to 'post-treatment bias' that conceals the effect of the institutional rules governing the formation of winning coalitions in the Council. However, since we also want to test the relationship between regulatory changes and legislative proposals, we include it in models 7-12, which also add a one-year lagged dependent 
variable (LDV). The bottom part of Table 1 shows results from the tests for serial correlation (mentioned above) and likelihood-ratio statistics for tests of overdispersion, which tests the nullhypothesis that the data satisfy the equidispersion restriction of the Poisson model (Long \& Freese 2006: 376-377). These tests provide strong evidence for overdispersion and show that the negative binomial model fits the data better than the Poisson model.

In model 1 we run a base model with only three variables: The percentage of winning coalitions in the Council, the number of EU member countries, and the Codecision-II dummy. To ease interpretation we report the regression coefficients in the form of so-called incidence-rate ratios (IRR) rather than the $\log$ of the expected count. The IRRs are exponentiated coefficients $\left(e^{\beta}\right)$, and show the factor change in the expected count of regulatory changes for a one-unit change in the explanatory variable, holding the other variables in the model constant (Long \& Freese 2006: 359$360)$. For purposes of interpretation, this means that IRRs larger than one $\left(e^{\beta}>1\right)$ correspond to a positive effect, while IRRs less than one $\left(e^{\beta}<1\right)$ correspond to a negative effect.

In model 1 , the results show that the percentage of winning coalitions in the Council has a positive effect on the number of regulatory changes. Recall that the number of winning coalitions is measured on scale from 0-100 percent, where higher values imply that it is easier to form winning coalitions in the Council and hence change status quo legislation. Specifically, a one-unit change in winning coalitions - corresponding to a one percent change - increases regulatory density by a factor of 1.16. In other words, a one percent increase in winning coalitions will, on average, result in a highly significant 16 percent increase in regulatory density per year. This effect is highly significant with a z-value close to six. Moreover, the result for the winning coalition variable is robust to different model specifications and changes in the set of control variables in Table 1, just as the magnitude of the coefficient is fairly stable throughout all models.

The increased number of member countries in the EU has also significantly increased the regulatory density across the eight sectors. By the estimate in model 1, an additional member state on average increases the yearly changes in regulatory density by around 8 percent. This result is also quite robust throughout the different models in Table 1 and statistically significant in all regressions except model 12. Although this finding might appear counterintuitive, it can be explained by the fact that new member states bring new preferences for standards and marketrelated rules into the EU. 
Table 1. Explaining Regulatory Reform in the EU, 1984-2012.

\begin{tabular}{|c|c|c|c|c|c|c|c|c|c|c|c|c|}
\hline Model & (1) & $(2)$ & (3) & $(4)$ & (5) & (6) & (7) & (8) & (9) & $(10)$ & $(11)$ & $(12)$ \\
\hline Regulatory reform t -1 & & & & & & & $\begin{array}{l}0.997 \\
(-0.40)\end{array}$ & $\begin{array}{l}0.991 \\
(-1.39)\end{array}$ & $\begin{array}{l}0.991 \\
(-1.20)\end{array}$ & $\begin{array}{l}0.989 \\
(-1.58)\end{array}$ & $\begin{array}{l}0.991 \\
(-1.27)\end{array}$ & $\begin{array}{l}0.994 \\
(-0.82)\end{array}$ \\
\hline Winning coalitions $_{t}$ & $\begin{array}{l}1.158^{* * *} \\
(5.97)\end{array}$ & $\begin{array}{l}1.143^{* * *} \\
(3.95)\end{array}$ & $\begin{array}{l}1.150^{* * *} \\
(5.47)\end{array}$ & $\begin{array}{l}1.132^{* * *} \\
(4.46)\end{array}$ & $\begin{array}{l}1.162^{* * *} \\
(4.94)\end{array}$ & $\begin{array}{l}1.129^{* * *} \\
(4.50)\end{array}$ & $\begin{array}{l}1.125^{* * *} \\
(3.09)\end{array}$ & $\begin{array}{l}1.158^{* * *} \\
(4.33)\end{array}$ & $\begin{array}{l}1.147^{* * *} \\
(3.69)\end{array}$ & $\begin{array}{l}1.150^{* * *} \\
(4.12)\end{array}$ & $\begin{array}{l}1.136^{* * *} \\
(3.01)\end{array}$ & $\begin{array}{l}1.097^{* *} \\
(2.23)\end{array}$ \\
\hline EU membership $_{\mathrm{t}}$ & $\begin{array}{l}1.081^{* *} \\
(2.28)\end{array}$ & $\begin{array}{l}1.097^{* * *} \\
(2.77)\end{array}$ & $\begin{array}{l}1.119^{* * *} \\
(3.23)\end{array}$ & $\begin{array}{l}1.147^{* * *} \\
(3.30)\end{array}$ & $\begin{array}{l}1.111^{* * *} \\
(2.88)\end{array}$ & $\begin{array}{l}1.120^{* * *} \\
(3.04)\end{array}$ & $\begin{array}{l}1.071^{*} \\
(1.79)\end{array}$ & $\begin{array}{l}1.107^{* * *} \\
(3.00)\end{array}$ & $\begin{array}{l}1.125^{* * *} \\
(3.41)\end{array}$ & $\begin{array}{l}1.170^{* * *} \\
(3.72)\end{array}$ & $\begin{array}{l}1.121^{* * *} \\
(3.40)\end{array}$ & $\begin{array}{l}1.081 \\
(1.54)\end{array}$ \\
\hline Codecision- $\mathrm{II}_{\mathrm{t}}$ & $\begin{array}{l}1.059 \\
(0.13)\end{array}$ & $\begin{array}{l}1.024 \\
(0.05)\end{array}$ & $\begin{array}{l}1.381 \\
(0.75)\end{array}$ & $\begin{array}{l}0.429 \\
(-1.29)\end{array}$ & $\begin{array}{l}0.978 \\
(-0.05)\end{array}$ & $\begin{array}{l}0.462^{* *} \\
(-2.43)\end{array}$ & $\begin{array}{l}1.186 \\
(0.36)\end{array}$ & $\begin{array}{l}1.042 \\
(0.09)\end{array}$ & $\begin{array}{l}1.535 \\
(0.90)\end{array}$ & $\begin{array}{l}0.391 \\
(-1.47)\end{array}$ & $\begin{array}{l}1.020 \\
(0.04)\end{array}$ & $\begin{array}{l}0.338^{* * *} \\
(-2.83)\end{array}$ \\
\hline Left-right Commission $_{t}$ & & $\begin{array}{l}1.013 \\
(0.26)\end{array}$ & & & & & & $\begin{array}{l}0.998 \\
(-0.03)\end{array}$ & & & & \\
\hline Left-right Council $_{t}$ & & & $\begin{array}{l}1.084 \\
(1.56)\end{array}$ & & & & & & $\begin{array}{l}1.090^{*} \\
(1.65)\end{array}$ & & & \\
\hline Left-right Parliament $_{t}$ & & & & $\begin{array}{l}1.100 \\
(1.19)\end{array}$ & & & & & & $\begin{array}{l}1.113 \\
(1.33)\end{array}$ & & \\
\hline Left-right max. distance ${ }_{t}$ & & & & & $\begin{array}{l}1.002 \\
(0.70)\end{array}$ & & & & & & $\begin{array}{l}1.006 \\
(1.26)\end{array}$ & \\
\hline $\operatorname{Thorn}_{\mathrm{t}}$ & & & & & & $\begin{array}{l}0.658 \\
(-0.58)\end{array}$ & & & & & & \\
\hline Delors $_{\mathrm{t}}$ & & & & & & $\begin{array}{l}0.881 \\
(-0.19)\end{array}$ & & & & & & $\begin{array}{l}0.316 \\
(-1.14)\end{array}$ \\
\hline Santer $_{\mathrm{t}}$ & & & & & & $\begin{array}{l}1.036 \\
(0.08)\end{array}$ & & & & & & $\begin{array}{l}0.496 \\
(-0.97)\end{array}$ \\
\hline Prodi $_{t}$ & & & & & & $\begin{array}{l}2.260^{* * *} \\
(3.17)\end{array}$ & & & & & & $\begin{array}{l}1.727^{*} \\
(1.82)\end{array}$ \\
\hline Leg. Proposals $\mathrm{t}_{\mathrm{t}-1}$ & & & & & & & $\begin{array}{l}1.003 \\
(0.72)\end{array}$ & $\begin{array}{l}1.000 \\
(0.01)\end{array}$ & $\begin{array}{l}1.002 \\
(0.45)\end{array}$ & $\begin{array}{l}1.000 \\
(-0.06)\end{array}$ & $\begin{array}{l}1.003 \\
(0.63)\end{array}$ & $\begin{array}{l}1.005 \\
(1.19)\end{array}$ \\
\hline Constant & $\begin{array}{l}2.349^{* *} \\
(2.08)\end{array}$ & $\begin{array}{l}2.160^{*} \\
(1.70)\end{array}$ & $\begin{array}{l}1.083 \\
(0.14)\end{array}$ & $\begin{array}{l}1.482 \\
(0.99)\end{array}$ & $\begin{array}{l}1.439 \\
(0.61)\end{array}$ & $\begin{array}{l}1.965 \\
(0.64)\end{array}$ & $\begin{array}{l}1.566 \\
(0.52)\end{array}$ & $\begin{array}{l}2.075 \\
(0.96)\end{array}$ & $\begin{array}{l}0.753 \\
(-0.26)\end{array}$ & $\begin{array}{l}1.326 \\
(0.37)\end{array}$ & $\begin{array}{l}0.781 \\
(-0.23)\end{array}$ & $\begin{array}{l}2.784 \\
(0.96)\end{array}$ \\
\hline Serial correlation test I & 0.74 & 0.23 & 0.25 & 0.16 & 0.23 & 0.58 & 0.81 & 0.96 & 0.95 & 0.78 & 0.94 & 0.32 \\
\hline Serial correlation test II & 0.77 & 0.26 & 0.26 & 0.16 & 0.26 & 0.62 & 0.83 & 0.97 & 0.96 & 0.80 & 0.95 & 0.37 \\
\hline Overdispersion & $287.3^{* * *}$ & $167.4^{* * *}$ & $155.3^{* * *}$ & $161.4^{* * *}$ & $159.2^{* * *}$ & $175.2^{* * *}$ & $199.8^{* * *}$ & $153.2^{* * *}$ & $138.2^{* * *}$ & $142.6^{* * *}$ & $140.4^{* * *}$ & $162.6^{* * *}$ \\
\hline Observations & 29 & 27 & 27 & 27 & 27 & 29 & 28 & 26 & 26 & 26 & 26 & 28 \\
\hline
\end{tabular}

\begin{tabular}{lllllllll} 
Observations & 29 & 27 & 27 & 27 & 27 & 29 & 28 & 26 \\
\hline Note. The dependent variable is the count of regulatory reforms (yearly changes in regulatory density). All models are estimated using negative binomial regression in Stata 12. Coefficients are incidence-
\end{tabular}

Note. The dependent variable is the count of regulatory reforms (yearly changes in regulatory density). All models are estimated using negative binomial regression in Stata 12 . Coefficients are incidence-
rate ratios. All variables are measured contemporaneously except legislative proposals and the LDV which are lagged one year. Serial correlation test I reports the $p$-value of the Portmanteau (Q) statistics. Serial correlation test II reports the $p$-value of the lagged residuals on current residuals. The overdispersion tests show the likelihood-ratio test statistics of the null-hypothesis that $\alpha=0$, i.e. that the data satisfy the equidispersion restriction. Standard errors are robust with z-statistics in parentheses. $* * * \quad \mathrm{p}<0.01, \quad * * \quad \mathrm{p}<0.05, \quad{ }^{*} \quad \mathrm{p}<0.1$. 
From a log-rolling perspective, this gives rise to more bargaining and vote-trading among member states, which may lead to a higher number of regulatory changes. Finally, the introduction of Codecision-II does not appear to have had any significant impact on regulatory reforms, once we control for the other variables in the model. This might be because the range of policy preferences represented in the Council are wider, or similar, to the range of policy preferences expressed in the Parliament, bringing no real change to the status quo winset.

In models 2-4 we add variables measuring the ideological position of the Commission (model 2), the Council (model 3), and the Parliament (model 4) on a one-dimensional left-right scale, using a recent dataset on the ideological composition of European institutions (Klüver \& Sagarzazu 2013). ${ }^{4}$ Moreover, model 5 adds a measure of the maximum ideological distance between EU institutions, which is part of the same data. We include this variable because ideological distance may capture the impact of heterogeneity in the policy preferences of veto players in the EU system, which could curb the ability of veto players to agree on implementing regulatory reforms. Interestingly, however, none of the political-ideological variables display any particular relationship with regulatory changes, and the ideological distance among veto players does not seem to matter either. This suggests that while institutional constraints on the ability to form winning coalitions in the Council do seem to affect regulatory reform, political constraints in the form of ideological heterogeneity seem to matter less.

Finally, in model 6 we add a full set of dummy variables for the Presidents of the Commissions, which are intended to capture idiosyncrasies related to the regulatory behaviour of the various Commissions during the period we examine. Since our data covers the period 19842012, we include dummy variables for Gaston Thorn (1981-1985), Jacques Delors (1985-1995), Jacques Santer (1995-1999), and Romano Prodi (1999-2004), while José Manuel Barroso’s presidency (2004-) serves as the reference category. In most cases, the Commissioner dummy variables are insignificant, the only exception being the Prodi dummy which is significantly positive. This means that relative to the Barroso Commissions, the Prodi Commission enacted significantly more regulatory changes within the sectors we examine.

In models 7-12, we replicate the regression in models 1-6, but add a lagged dependent variable and the variable measuring the number of legislative proposals. However, the LDV is always insignificant - as we would expect given the lack of trend and persistency in the data - and has little effect on the results for the other explanatory variables. The number of legislative proposals is

\footnotetext{
4 The time series of these data end in 2010 , and therefore we lose two observations.
} 
measured on a scale from zero and onwards. Based on model 7, a one unit increase in legislative proposals in the previous year $\left(t_{-1}\right)$ increases the number regulatory changes (at time $t$ ) by a factor of 1.003. This means that each additional legislative proposal issued by the Commission (a one-unit change) will on average produce a $0.3 \%$ increase in regulatory density. However, the effect of legislative proposals is insignificant in all models. This means that there does not appear to be a systematic relationship between the legislative proposals put forward by the Commission and the number of regulatory changes that are actually implemented.

Indeed, the most noteworthy result in models $7-12$ is that the winning coalition variable continues to be positive and highly significant. Even controlling for a host of other factors, regulatory changes within the eight industries in our data seem to be systematically affected by changes in the institutional rules that govern the making of winning coalitions in the EU Council. That is, the volume of regulatory reforms has systematically decreased as it has become more difficult for member states to form winning coalitions in the Council. This result strongly suggests that institutional constraints on decision-making powers - and the ability of countries to form winning coalitions in the EU council - seem to be the key factor enabling or restraining regulatory changes within the EU system.

The findings of this analysis partly confirm some of the theoretical claims made in the literature on the EU legislative process. In particular, the results of the empirical analysis point to three main findings. First, there is clear evidence that the voting rules in the Council have a powerful impact on the dynamics of regulatory reform in the EU. More specifically, our findings suggest that the ability to form winning coalitions in the Council has a strong and significant influence on the pace and volume of regulatory reform. This is in line with veto player theory, which predicts that the winset of the status quo tends to expand as we move from unanimity voting to lower thresholds for QMV (Tsebelis 2002: 41). Second, the enlarged membership of the EU has a significant impact on regulatory reform. However, an increased membership of the EU does not seem to result in the maintenance of the regulatory status quo, but in an increase in regulatory density, as more diverse policy preferences are being incorporated in new legislation through log-rolling and bigger 'package deals'. Third, the political composition of the EU legislative bodies does not have a significant impact on the dynamic of regulatory reform in the EU. Although ideological incongruence can slow down the pace of decision-making (Klüver \& Sagarzazu 2013), it does not seem to significantly affect the number and volume of regulatory reforms. Overall, these findings 
suggest that institutional constraints and EU membership size have systematic - but countervailing effects - on regulatory reform within the EU.

\section{Conclusion}

This paper has analysed the general dynamics of stability and change in EU regulatory legislation and investigated the sources of regulatory reform. To this end, we have developed an original dataset measuring yearly changes in regulatory density across eight sectors during the period 19842012. Using this data, we have examined the impact of a number of institutional and political variables on regulatory change within the EU.

The key finding of the empirical analysis is that the number of winning coalitions in the Council - a measure of the ability to build coalitions within the constraints of voting rules in the Council - contributes significantly to explain changes in regulatory legislation. Moreover, there is clear evidence that the increased membership of the EU has had a significant impact on regulatory changes within the eight sectors, which is arguably a consequence of the log-rolling dynamics taking place whenever the EU legislative system is 'forced' to accommodate to increasing heterogeneity in policy preferences for regulatory standards among its member states. However, looking at the political sources of regulatory change, we have not found systematic evidence that the Commission's policy entrepreneurship significantly affects regulatory reform in the EU. Relative to the incumbent Barroso Commission, only Prodi's Commission was significantly more active in the area of regulatory reform. Finally, we have not found significant evidence that the ideological composition and distance of the Commission, the Parliament, and the Council have a significant impact on regulatory changes. Indeed, regulatory reform seems to have proceeded quite independently of the ideological orientation of EU's key legislative bodies. That is, while conventional ideological positions do not appear to be a key source of regulatory reform, institutional constraints on decision-making powers do matter for the magnitude of regulatory reform. These findings suggest that institutions trump politics in terms of explaining regulatory reform within the EU. However, whether this pattern generalises to policy areas outside the sectors we have analysed remains an open question that needs to be addressed in future work. 


\section{References}

Baskoy, T. (2008)., The Political Economy of European Union Competition Policy: a Case Study of the Telecommunications Industry, New York: Routledge.

Baumgartner, F. R. \& Jones, B. D. (2002). Policy Dynamics. Chicago: University of Chicago Press.

Baumgartner, F. R. \& Jones, B. D. (1993). Agendas and Instability in American Politics. 1st ed. Chicago: University of Chicago Press.

Cameron, A. C. \& Trivedi, P. K. (2005). Microeconometrics: Methods and Applications. Cambridge: Cambridge University Press

Cashore, B. \& Howlett, M. (2007). Punctuating Which Equilibrium? Understanding Thermostatic Policy Dynamics in Pacific Northwest Forestry. American Journal of Political Science 51(3): 532-551.

Citi, M. (2013). EU budgetary dynamics: incremental or punctuated equilibrium? Journal of European Public Policy 20(8): 1157-1173.

Coleman, W. D., Skogstad, G. D. \& Atkinson, M. M. (1996). Paradigm Shifts and Policy Networks: Cumulative Change in Agriculture. Journal of Public Policy 16(3): 273301.

Egan, M. (2001). Constructing a European Market: Standards, Regulation, and Governance. Oxford: Oxford University Press.

Gabel, M. \& Hix, S. (2002). Defining the EU political space: An empirical study of the European elections manifestos, 1979-1999. Comparative Political Studies 35(8): 934-964.

Hage, F. M. (2011). The European Union Policy-Making Dataset. European Union Politics 12(3): 455-477.

Hall, P. A. (1993). Policy Paradigms, Social Learning, and the State: The Case of Economic Policymaking in Britain. Comparative Politics 25(3): 275-296.

Harcourt, A. J. \& Radaelli, C. (1999). Limits to EU Technocratic Regulation? European Journal of Political Research 35(1): 107-122.

Henstra, D. (2011). The Dynamics of Policy Change: A Longitudinal Analysis of Emergency Management in Ontario, 1950-2010. Journal of Policy History 23(3): 399-428. 
Héritier, A., Kerwer, D., Knill, C., Lehmkuhl, D., Teutsch, M. \& Douillet, A-C. (2001). Differential Europe: The European Union Impact on National Policymaking. Lanham, Md.: Rowman \& Littlefield Publishers.

Hix, S. (2008). What's Wrong with the European Union and How to Fix It. Cambridge: Polity.

Hosli, M.O. (1999). Power, Connected Coalitions, and Efficiency: Challenges to the Council of the European Union. International Political Science Review 20(4): 371-391.

Howlett, M. \& Cashore, B. (2009). The Dependent Variable Problem in the Study of Policy Change: Understanding Policy Change as a Methodological Problem. Journal of Comparative Policy Analysis: Research and Practice 11(1): 33-46.

Jones, B. D. \& Baumgartner, F. R. (2005). The Politics of Attention: How Government Prioritizes Problems. University Of Chicago Press.

Jones, B. D., Baumgartner, F. R., Breunig, C., Wlezien, C., Soroka, S., Foucault, M., François, A., Green-Pedersen, C., Koski, C., John, P., Mortensen, P.B., Varone, F., \& Walgrave, S. (2009). A General Empirical Law of Public Budgets: A Comparative Analysis. American Journal of Political Science 53(4): 855-873.

Jones, B. D., Sulkin, T., \& Larsen, H. A. (2003). Policy Punctuations in American Political Institutions. American Political Science Review 97(1): 151-169.

Kassim, H. \& Stevens, H. (2010). Air Transport and the European Union. Basingstoke: Palgrave Macmillan.

Klüver, H. \& Sagarzazu, I. (2013). Ideological Congruency and Decision-Making Speed: The Effects of Partisanship across European Union Institutions. European Union Politics 14(3): $388-407$

Knill, C., Schulze, K. \& Tosun, J. (2012). Regulatory policy outputs and impacts: Exploring a complex relationship. Regulation \& Governance 6(4): 427-444.

König, T. \& Bräuninger, T. (2004). Accession and Reform of the European Union A GameTheoretical Analysis of Eastern Enlargement and the Constitutional Reform. European Union Politics 5(4): 419-439.

Kreppel, A. \& Tsebelis, G. (1999). Coalition formation in the European parliament.

Comparative Political Studies 32(8): 933-966.

Long, J. S. \& Freese, J. (2006). Regression Models for Categorical Dependent Variables Using Stata. Texas: Stata Press.

Majone, G. (1996). Regulating Europe. Oxford, New York: Routledge. 
Peterson, J. (1999). The Santer Era: The European Commission in Normative, Historical and Theoretical Perspective. Journal of European Public Policy 6(1): 46-65.

Pollack, M. A. (2003). The Engines of European Integration: Delegation, Agency, and Agenda Setting in the EU. Oxford: Oxford University Press.

Quaglia, L. (2007). The politics of financial services regulation and supervision reform in the European Union. European Journal of Political Research 46(2): 269-290.

Scharpf, F. W. (1996). Negative and Positive integration in the Political Economy of European Welfare States. In G. Marks, F. W. Scharpf, P. C. Schmitter \& W. Streeck (eds), Governance in the European Union. London: Sage.

Tsebelis, G. (2002). Veto Players: How Political Institutions Work. Princeton: Princeton University Press.

Tsebelis, G. (2006). The European Convention and the Rome and Brussels IGCs: A veto players analysis. In T. König \& S. Hug (eds), Policy-making Processes and the European Constitution: A Comparative Study of Member States and Accession Countries. London: Routledge: 9-22.

Tsebelis, G. (2012). From the European Convention to the Lisbon Agreement and Beyond: A Veto Player Analysis. In D. Finke, T. König, S.-O. Proksch, \& G. Tsebelis, (eds), Reforming the European Union: Realizing the Impossible. Princeton: Princeton University Press: 28-61.

Tsebelis, G. \& Garrett, G. (2000). Legislative politics in the European Union. European Union Politics 1(1): 9-36.

Veen, T. (2011). The Political Economy of Collective Decision-Making: Conflicts and Coalitions in the Council of the European Union. Springer.

Young, A. R. (2007). The Politics of Regulation and the Internal Market. In K. E. Jørgensen, M. Pollack and B. Rosamond (eds), Handbook of European Union Politics. London: Sage.

Zimmer, C., Schneider, G., \& Dobbins, M. (2005). The Contested Council: Conflict Dimensions of an Intergovernmental EU Institution. Political Studies, 53 (2), 403422. 